Provided for non-commercial research and education use. Not for reproduction, distribution or commercial use.

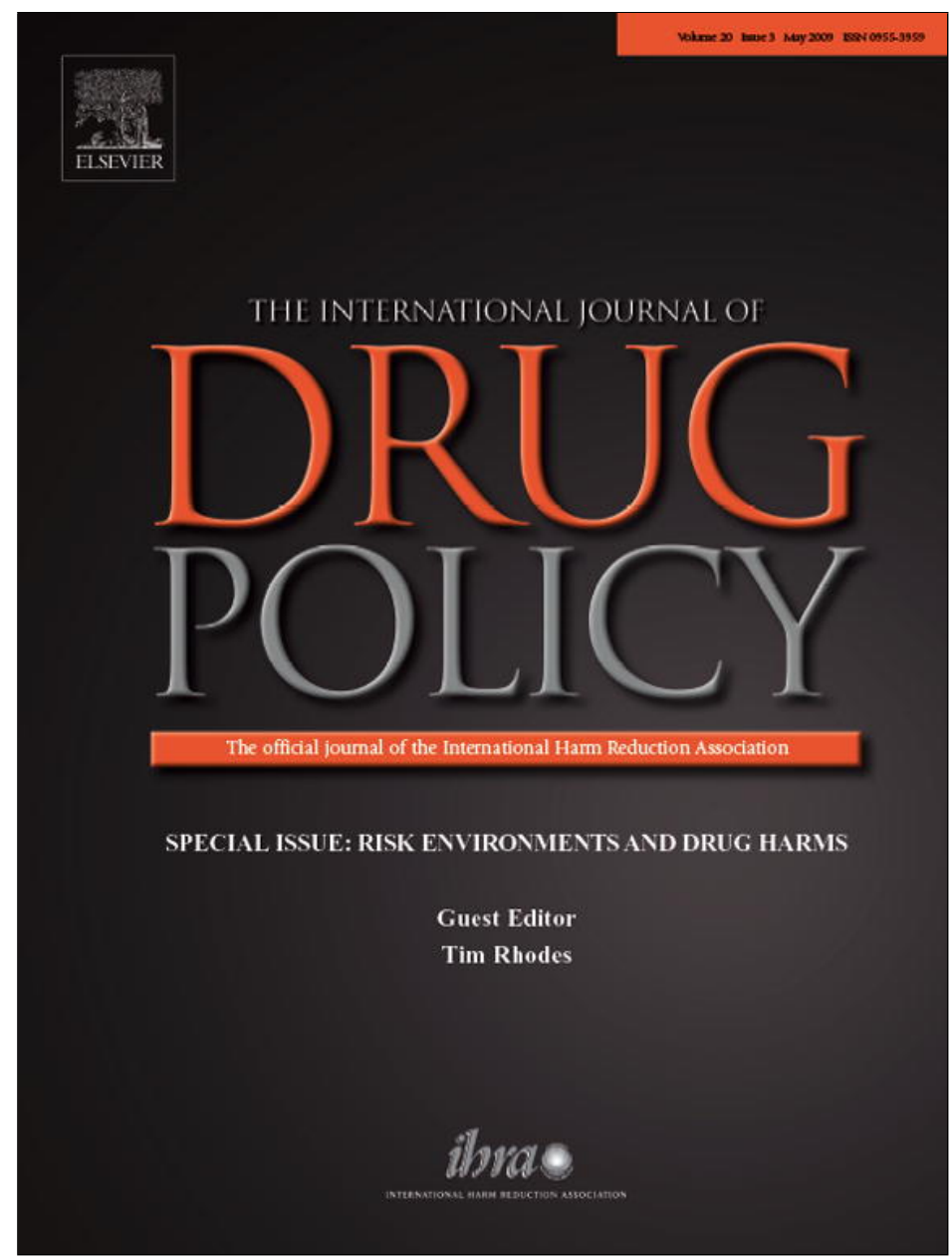

This article appeared in a journal published by Elsevier. The attached copy is furnished to the author for internal non-commercial research and education use, including for instruction at the authors institution and sharing with colleagues.

Other uses, including reproduction and distribution, or selling or licensing copies, or posting to personal, institutional or third party websites are prohibited.

In most cases authors are permitted to post their version of the article (e.g. in Word or Tex form) to their personal website or institutional repository. Authors requiring further information regarding Elsevier's archiving and manuscript policies are encouraged to visit:

http://www.elsevier.com/copyright 
Research paper

\title{
The mutual extraction industry: Drug use and the normative structure of social capital in the Russian far north
}

\author{
Hilary Pilkington ${ }^{\mathrm{a}, *}$, El'vira Sharifullina ${ }^{\mathrm{b}}$ \\ a Department of Sociology, University of Warwick, Coventry CV4 7AL, United Kingdom \\ b Scientific Research Centre 'Region', Ul'ianovsk State University, Ul. Pushkinskaia 13, Office 118, 432049 Ul'ianovsk, Russia
}

\section{A R T I C L E I N F O}

\section{Article history:}

Received 10 May 2008

Received in revised form 7 August 2008

Accepted 9 August 2008

\section{Keywords:}

Youth

Social capital

Social networks

Russia

\begin{abstract}
A B S T R A C T
Background: The article contributes to the literature on the role of social networks and social capital in young people's drug use. It considers the structural and cultural dimensions of the 'risk environment' of post-Soviet Russia, the micro risk-environment of a deindustrialising city in the far north of the country and the kind of social capital that circulates in young people's social networks there. Its focus is thus on social capital at the micro-level, the 'bridging' networks of peer friendship groups and the norms that govern them.

Method: The research is based on a small ethnographic study of the friendship groups and social networks of young people in the city of Vorkuta in 2006-2007. It draws on data from 32 respondents aged 17-27 in the form of 17 semi-structured audio and video interviews and field diaries. Respondents were selected from friendship groups in which drug use was a regular and symbolically significant practice.

Results: The risk environment of the Russian far north is characterised by major deindustrialisation, poor health indicators, low life expectancy and limited educational and employment opportunities. It is also marked by a 'work hard, play hard' cultural ethos inherited from the Soviet period when risk-laden manual labour was well-rewarded materially and symbolically. However, young people today often rely on informal economic practices to generate the resource needed to fulfil their expectations. This is evident from the social networks among respondents which were found to be focused around a daily routine of generating and spending income, central to which is the purchase, sale and use of drugs. These practices are governed by norms that often invert those normally ascribed to social networks: reciprocity is replaced by mutual exploitation and trust by cheating.

Conclusions: Social networks are central to young people's management of the risk environment associated with post-Soviet economic transformation. However, such networks are culturally as well as structurally determined and may be sites not only of cooperation, support and trust but also of mutual exploitation, deceit and distrust. This does not imply these regions are devoid of social capital. Rather it suggests that the notion of social capital as a natural by-product of a self-regulating economy and its institutions needs to be reconsidered in the context of local configurations of capital and social relations as well as their cultural and normative context. This reconsideration should include further reflection on whether the kinds of social networks described might be better understood not as motors for the generation of social capital but as sites of its 'mutual extraction'.
\end{abstract}

(C) 2008 Published by Elsevier B.V.
The complex connection between deindustrialisation, social exclusion and risk-taking is well-established in the study of young people's drug use in the United Kingdom (MacDonald \& Marsh, 2005, pp. 170-89; Pearson, 1987, p. 74; Shildrick, 2002). Moreover, where structural dislocation is associated with major social and economic transition - such as in the former Soviet Union

\footnotetext{
* Corresponding author. Tel.: +44 24765 75128/74756; fax: +44 247623497. E-mail address: h.pilkington@warwick.ac.uk (H. Pilkington).
}

and Central and Eastern Europe - particular 'risk environments' emerge in which structural factors and personal decisions combine to facilitate intravenous drug use and the associated rapid spread of HIV (Rhodes \& Simic, 2005; Rhodes, Singer, Bourgois, Friedman, \& Strathdee, 2005). Yet, not all people, neighbourhoods or communities affected by economic restructuring and its consequent social dislocation engage in such practices or fail to adopt appropriate harm reduction techniques when they do. This has led researchers to explore what lies between structural conditions and individual drug use behaviours that might explain this. For epidemiological, public health and policy research key variables include patterns 
of inter-personal communication, inclusion/exclusion from social institutions, information provision, and access to health, including harm reduction, facilities. Another factor gaining increasing attention - and of particular interest to sociologists researching drug use - is 'social capital'.

The interest in social networks and social capital follows from research into economic transformation and health outcomes, which suggests social cohesion is 'a crucial determinant of population health' (Kennedy, Kawachi, \& Brainerd, 1998, p. 2029). At the micro-level published research provides evidence that social relationships such as parental support (Springer, Parcel, Baumler, \& Ross, 2006), sexual partnerships (Rhodes \& Quirk, 1998) and friendship groups (Pilkington, 2007b) manage and mediate risk environments. This suggests that 'social networks' (Latkin, Forman, Knowlton, \& Sherman, 2003, p. 472) and 'social capital' (Lovell, 2002 , p. 806) may act as protective factors in reducing risk associated with drug use and risky sexual practices.

This research into drug use confirms the significance of the notion of social capital in illuminating the 'value added' to society of social connectivity as indicated by Putnam's classic study of the relative political effectiveness of regional governments in Italy (Halpern, 2005, p. 8) and reflected in the application of social capital by economists to account for the "residual" economic growth beyond that explained by physical and human capital' (Fine \& Green, 2000, p. 89). However, in seeking to explain the relationship between risk environment and individual behaviour more concretely, it is important to avoid understanding 'social capital' as the pivot around which a virtuous circle turns; social connections breed familiarity and trust, which foster cooperation and social stability, which, in turn, confirm trust and encourage social connectivity. Indeed, as noted already by Rhodes et al. (2005, p. 1032) when 'social capital' is used in this way as a proxy for the general level of political and economic stability, it becomes difficult to isolate its particular value for understanding vulnerability to risk-taking practices. Indeed, evidence from empirical studies of drug users provides conflicting evidence on the role of social networks. Lalander (2003, p. 27), for example, notes that the 'feeling of community and belonging and shared experience' promoted by drug use allows young people to extend their social ties and deepen social bonds. At the same time, addictive drug use has long been associated with the withdrawal from social networks (see for example Parker, Bakx, \& Newcombe, 1988, p. 52; Zinberg, 1984, p. 77). Drug users report that the onset of addictive drug use sees 'genuine' friendships turn into pragmatic associations - 'necessary companions in [their] pursuit of drugs' (Sherman, Smith, Laney, \& Strathdee, 2002, p. 116) - and a withdrawal from friendship (Pearson, 1987, p. 56). Lalander's (2003, p. 65) ethnographic study of drug users in a deindustrialising Swedish city thus concludes that the drug use that at first cements social bonds gradually becomes something which dictates the individual's social life and causes them to become 'more and more solitary'.

If being socially 'connected' can both encourage and inhibit risky practices, it follows that the successful application of the notion of 'social capital' in the field of drug use requires a consideration of not just the presence or absence of social connections and networks but the nature of those networks and of the value they produce. This is not new-the cultural embeddedness of social capital is recognised by both Putnam (1995, p. 665), who defines it as 'social connections' and their 'attendant norms and trust', and by Reimer, Lyons, Ferguson, and Polanco (2008, p. 258), who point to the significance of the normative structures in which social capital is embedded. The substantive part of this article thus takes a step back from the question of how particular social networks might impact on individuals' drug-use practices and instead seeks to contribute to teasing out how the economic, social and cultural dimensions of a particular risk-environment are manifested in the normative structure of micro-level social relations and reflect on the implications of this for our understanding of social capital located there. To this end, although the broader ethnographic study of peer-based social connections it draws on includes material on young people's drug using careers and practices, in this article drugs are considered primarily from the perspective of their role as a commodity for sale, exchange and group relaxation.

\section{Method}

This paper draws on empirical work conducted as part of a transnational European project on Society and Lifestyles: Towards Enhancing Social Harmonisation through Knowledge of Subcultural Communities (SAL), 2006-2008. The research was not designed to investigate drug use as a distinct 'subcultural' practice or to study 'drug users' in isolation from broader youth cultural scenes. Rather, drawing on our previous work (Pilkington, 2007a), we were interested particularly in the role of the friendship group (kompaniia) in mediating young people's drug use and the research was centred not on interview-based narratives of drug use and risk management but on observing the drug practices of young people from within the group context and as part of the full spectrum of everyday cultural practices.

The project was designed around two 6-week periods of ethnographic research in the city of Vorkuta, Russia in autumn 2006 and 2007. (El'vira Sharifullina was the principal field researcher, Hilary Pilkington joined her for 2 weeks in each year.) In line with the rationale set out above, respondents were not sought solely on the basis of their reported drug use but rather with regard to their willingness to introduce the researchers to their friendship group. It was essential that drug use was a regular and symbolically significant practice within the group but not that the group met primarily for the purpose of drug use or that all members of the group were drug users. A number of starting points for developing access to groups were initiated upon arrival in Vorkuta; these drew on contacts from earlier research in the city and from everyday encounters with young people. Consequently the study can be described as including a total of 32 respondents ( 26 male, 6 female) aged 17-27 but centring on a core group of around 10 young people who took part in both stages of the research and were part of the same, broadly defined, 'friendship group'. Of the 32 respondents, 18 reported previous or current illicit substance use (that is use of narcotic substances not including alcohol and tobacco). Of the 10 core respondents, all except one had extensive current or past drug use experience. Over the course of the research (especially between the first and second fieldwork periods) the drug careers and degree of participation in the networks originally identified changed for a number of respondents. Where this is considered to be important for understanding respondents' reflections on their lives, it is noted at the relevant point in the text.

The materials analysed for this article are: 17 semi-structured audio and video interviews; and field diaries written by both authors. A parallel case study with another group of young people was conducted in the city at the same time under the auspices of the SAL project (principal field researcher, Al'bina Garifzianova). Although the two case studies were thematically differentiated and the field researchers worked independently, some practices (including drug use) were common across both case studies and some respondents were known to both researchers (they shared living space and close informants sometimes hung out at the researchers' flat). However, in this article, material is drawn only from those respondents who formally belong to the case study of 'drug users' with the exception of one interview extract ('Roman', 
see below) concerning the city environment in general. Both audio and video interviews were transcribed in Russian and analysed using NVivo7. Recorded interviews and conversations were coded in their entirety and while codes related to 'substance use' and 'kompaniia' (friendship group) constituted a significant bloc of codes for this case study, a number of other categories also produced rich data. This is not surprising; as Bourgois (2003, p. 2) notes in his classic ethnography of crack cocaine sellers in East Harlem, respondents want to share their whole lives with researchers and are 'not interested in talking primarily about drugs'. One such category is that of 'material relations', which includes eight subcategories and is drawn on extensively in this article. Codes and their sub-categories were derived as a mixture of 'authentic' codes drawn from the informants' linguistic repertoire (e.g. razvod, kompaniia, kidat') while others were described by English-language terms imbued with some external, theoretical content (e.g. 'substance use', 'material relations', 'trust'). The significance of social connections emerged during the course of data analysis, however, as the relationship between codes was interpreted. Thus, the notion of 'social capital' was introduced at this later stage as a way of making sense of the lives in which the authors had shared. Field diaries were analysed in the same way as interviews although located as a separate sub-category of documents.

The ethnographic approach underpinning the research conformed to the structure of the wider transnational project, which allowed for two 6-week periods of field research. This necessitated the very rapid development of relations with respondents and led the main field researcher to take more risks than usual in so doing. Moreover, the holy grail of establishing the 'trust' that marks acceptance into a community under study for the ethnographer turned out, in this instance, to be a fool's gold since the friendship group in which she moved was itself not predicated on mutual trust but on 'communication in a world of total deception [in which] if you cheat someone, that's cool, if you are cheated, you're a div.' (Sharifullina, Fieldwork diary, 2nd October 2006). This manifested itself also in the reluctance of some respondents to give recorded interviews (at least in 2006). Although the research was conducted overtly and all respondents knew that anonymity would be ensured (all names in this article are pseudonyms), some remained concerned that the information accumulated by the researchers could be turned against them or, more precisely, that it might be used by others to their advantage. As is discussed below, knowledge about others is viewed by these young people as a potential source of power and profit. While it is impossible to claim that these ethical issues were fully resolved, the ethnographic process allowed the researcher and researched to discuss the issues informally and repeatedly. While power within the research process was not removed, therefore, it was at least diffused.

\section{From hero to (below) zero: structural and cultural dimensions of Vorkuta's risk environment}

Vorkuta is a rapidly deindustrialising and depopulating city in the far north of European Russia. As such it epitomises what Flaker (2002, p. 455) refers to as the 'grim industrial complexes that were built to meet the needs of a previous era' in which 'for many, drug or alcohol-induced oblivion is the only way to make life bearable'. Since 1991, the majority of Vorkuta's mines have closed leading to the abandonment of whole districts (poselki) and a feeling that the city is being slowly wound down. Vorkuta's economic crisis is compounded by its territorial location (see Plate 1 ). The city lies $2266 \mathrm{~km}$ to the North East of Moscow and connection to the outside world is primarily via rail; there are no road connections to other cities and the small airport links directly only to the Komi Republic capital, Syktyvkar. In the winter - which lasts around 230 days of the year - the temperature can fall as low as $-52^{\circ}$. The economic and territorial isolation of Vorkuta is fuelling a process of rapid out-migration; in 1995 the city's population was 181,000, by 2007 it had fallen to 120,000 (all official statistical data are taken from a number of on-line sources detailed at the end of the article).

Registered unemployment (3.3\%) is low but educational and employment prospects are nonetheless limited. The city's economy remains heavily dependent upon the extraction of coal (74\% of the city's industrial production) and further and higher educational establishments are oriented towards training skilled workers for employment in the mines. Thanks to the premiums paid to extraction sector workers, average monthly wages remain relatively high; in 2006, average salaries were 1.5 times higher than the Russian national average.

The climatic conditions of life in Russia's far north have serious negative impacts on the health of individuals causing, in particular respiratory, circulation and metabolic problems (Round, 2006, p. 20). Health indicators for Komi Republic in 2006 show an average life expectancy of 58 years for men and 71 for women, which is below the Russian national average of 60 and 73, respectively. Anecdotal evidence puts male life expectancy in Vorkuta still lower; when justifying illegal substance use respondents joked that, since they were only going to live to the age of 56 anyway, they might as well 'enjoy life'. A heightened openness to 'risk' is also suggested by the findings of our earlier research on drug use, which showed that, despite the remoteness of Komi Republic, rates of life-time reported illicit substance use among young people were higher in Komi Republic (29.2\%) than the comparison regions, Samara oblast' (16.5\%) and Krasnodar krai (15.9\%) in both of which cannabis was grown domestically and other drugs were well supplied through established drug trafficking routes (Pilkington, 2007a, p. 217). Since that research (2002-2003), the range of drugs available in Vorkuta has significantly expanded; particularly noticeable was the extension of 'recreational' drug use from cannabis ('grass' and resin) to amphetamines including a wide range of 'Ecstasy-style' tablets collectively referred to as 'tabli' or individually by more specific brand-names (e.g. 'Swallows', 'Mitsubishi', 'Love') or, when in powdered form, 'spidy'.

The structural dislocation of post-Soviet Russia, and other 'transition' societies, leads them to be understood as lacking in social capital (Halpern, 2005, p. 101; Round, 2006, p. 29). This is measured typically by low levels of civic participation and universal, anonymous trust; 'trust in strangers' in Russia, for example, has been shown to be consistently low over the post-Soviet period at 22-25\% (Kertman, 2006, pp. 22-23; Rose, 1995, p. 38). This leads McKee (2002, p. 456) to suggest that 'transition societies' display classic characteristics of anomie, producing young people 'characterised by a sense of futility, lack of purpose, emotional emptiness and despair'. However, a culturally nuanced approach to social capital is beginning to be employed in relation to Russia to challenge this vision of a country suffering social capital deprivation (see, for example, White, 2004; Yates, 2005). Round (2006, p. 27), drawing on a study of the survival strategies of Gulag survivors in the Russian far north, argues that social capital - including material and emotional trust - levels are, in fact, high, but are embedded in social networks and detached from state institutions. This confirms Rose's (1995, p. 38) earlier contention that post-communist Russia might be envisaged not as anomic but as an 'hour-glass society' in which there are strong ties between individuals (reflected in high levels of trust in people they know) but widespread 'distrust of the top half of society'.

In seeking to understand the relationship between the structural conditions underpinning the 'risk environment' and individual responses to it in this particular micro-environment, it may be help- 


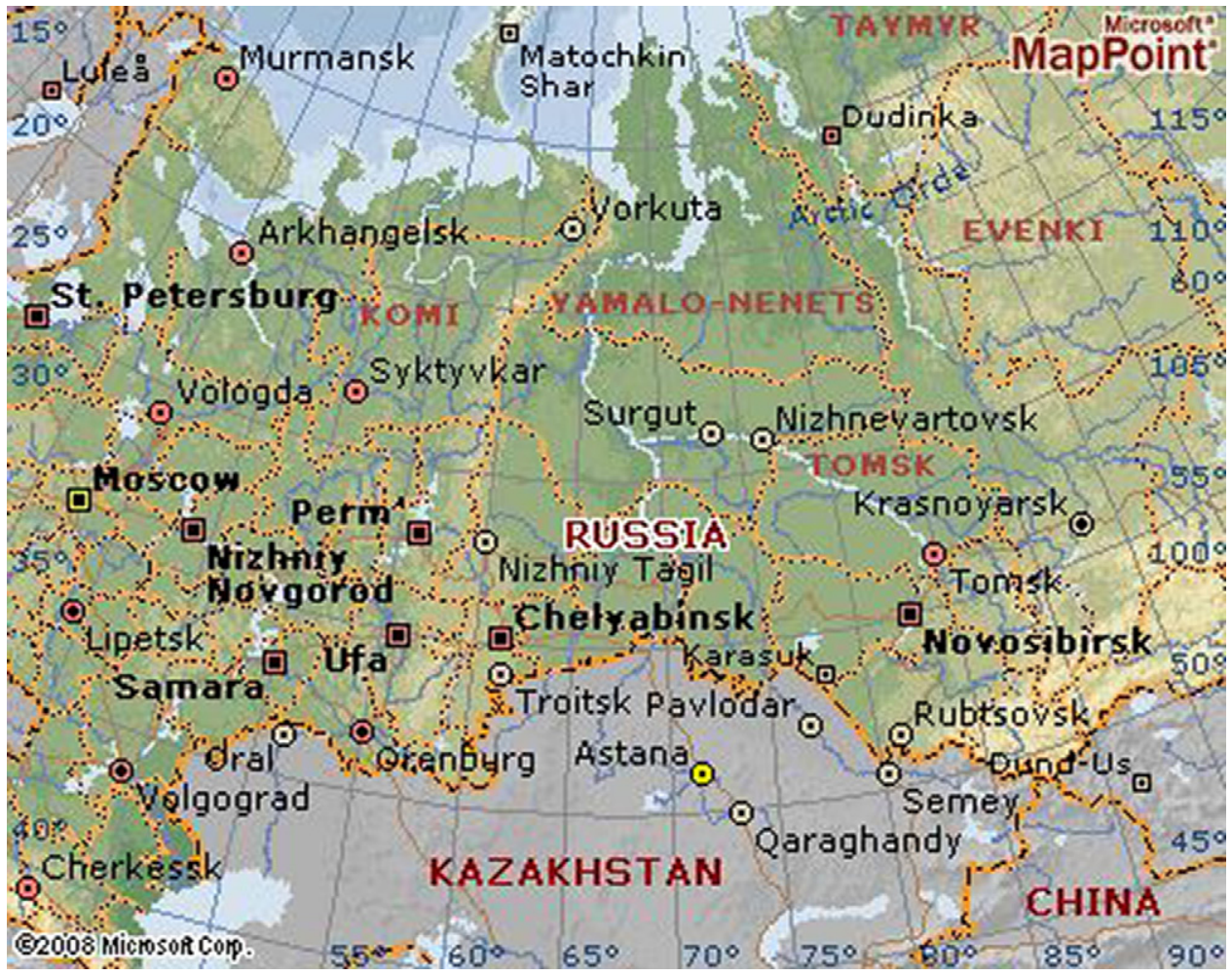

Plate 1. The geographic location of Vorkuta.

ful to return to Bourdieu's understanding of the role of social, as well as other forms of, capital in the reproduction of social relations. According to Bourdieu (1977, p. 184), social, cultural and symbolic capital are the means by which 'objective, institutionalized mechanisms' of relations of domination are maintained in modern industrial societies. It is, he says, the objectification of accumulated social capital that 'guarantees the permanence and cumulativity of material and symbolic acquisitions which can then subsist without the agents having to recreate them continuously and in their entirety by deliberate action' (Bourdieu, 1977). This vision of a self-regulating market (Bourdieu, 1991, p. 186) in which economic, cultural and symbolic capital is 'objectified', transferred and reproduced more or less unnoticed by social agents, however, is not readily transferred to post-Soviet Russia where rapid economic transformation has rendered forms of domination visible and undermined the legitimacy of the capital(s) that underpin it. This, it might be argued, is particularly true of the northern territories of Russia which, having benefited in the Soviet period from targeted inward investment and protection from national or international competition, found that, following the collapse of the Soviet Union, industrial production went into rapid decline reducing large proportions of the population to living on incomes below the subsistence level (Round, 2005, p. 713). Thus, economic transformation since 1991, at one level, has reoriented society towards impersonal market transactions in which standardized forms of economic and cultural capital are recognisable, but on the other, post-communist marketisation has facilitated the 'reconstitution of the former nomenklatura into new owners, entrepreneurs, and political elites' along with their former social networks and practices (Outhwaite \& Ray, 2005, p. 166). There is a strong argument, therefore, that relations of domination in contemporary Russian capitalism are characterised by transparency and subjectification rather than the opacity and objectification of which Bourdieu (1977, p. 184) talks. The question then arises as to how these capital relations are played out at the micro-social level. If social, and other, capitals are not objectified mechanisms for the reproduction of domination relinquishing the need for personal agency and intervention to sustain such domination, might we not also expect economic, social, cultural and symbolic capital not simply to accrue from social connectivity but to have to be repeatedly 'won' and protected from reappropriation? And if so, is that capital not likely to be accompanied by norms and practices other than those of mutual support and cooperation usually associated with social capital?

The laying bare of relations between capital and labour, we suggest, is a significant aspect also of the cultural dimension of the 'risk environment' in which our respondents move. The city is not only depopulating physically but is being emptied of symbolic signification too. Vorkuta did not grow organically but was a seedling planted in inhospitable climes with a single purpose; to extract coal from the Pechora coal basin and provide the rapidly industrialising Soviet Union with its life-blood. It was founded on the basis of involuntary labour (Pilkington, 2007a, p. 221) and our respondents included individuals whose grandparents had been part of the original Gulag construction brigades that built the mines or had worked as prison camp guards. For other respondents it was their parents who had first come to Vorkuta in order to take advantage of the higher wages offered under the Soviet regime to compensate for the heightened risk and the harsh climatic conditions of working in the region (see also Round, 2005, pp. 709-711). While almost all came with the intention of staying temporarily, the material privileges enjoyed meant many had remained in the city all their working lives. Today, however, the relative material advantage of remaining in Vorkuta is declining and the current generation of young people is often resentful that the past recognition of miners' labour is denied them:

If only, if only there were some kind of future prospects here, of living at least like people did in the past, like my parents for example. Take the 1980s, when miners really did [laughs] earn decent money and lived well. I remember my Mum's brother, my 
uncle, coming here... He was just 5 or 6 years older than me. At that time, when he was working here, when he lived here, they didn't let themselves get down. At the end of the week, on Friday they would buy tickets... and fly to Moscow. There they went out to restaurants, relaxed, had a drink. Everything was superb. Hmm - it was like Saturday was their day. On Saturday they partied and on Sunday they flew back, went to work again and that's how it was every week.

(Murzilka, 27, former heroin user, current cannabis and amphetamine user 2006)

The cultural memory of material comfort, mobility (long and well paid holiday entitlements) and - notwithstanding Soviet ideology - a 'work hard, play hard' ethic is deeply entrenched in the city's inhabitants and is central to understanding the work and life strategies of young people in Vorkuta today. The high symbolic value attached to manual productive labour in the Soviet system of values together with the particular perception of the risk taken by those working in the mines, lent miners a cult status in the Soviet Union. Cities such as Vorkuta, whose identity was wholly lodged in such 'heroic labour', were revered and their inhabitants were encouraged to value their 'sacrifice' by celebrating their contribution to the national economy and enjoying the material rewards with which they were compensated. Today, however, VorkutaCoal (which owns the mines) can no longer sustain the desired lifestyle of its residents and its attempts to evoke a sense of security (and future) among the population appear increasingly flimsy (see Plate 2 ).

In a self-fulfilling logic, therefore, the city's inhabitants stay while there is coal to extract, and while the inhabitants stay, Vorkuta continues to exist. Who or what is driving this set of mutual dependencies is not clear, but respondents sense it is not them:

Respondent: This city is just a ghetto...

Interviewer: How do you mean? A ghetto usually means a place you are trapped in.
Respondent: Well, everyone is kept here by the work, nothing else... The city manipulates these people. Here, those who can earn themselves a bit of money, accumulate contacts, they get out of here... Everyone wants to leave but they live here all the same. That's what a ghetto is.

(Roman, 21, regular cannabis and amphetamine user, 2007)

Here Roman captures the sense among Vorkuta inhabitants that it is no longer natural but human resources that are being 'extracted' but he also identifies the strategy for resisting this 'manipulation'. The smart ones ('those who can'), he says, accumulate economic and social capital as an exit strategy. This accumulation of social capital by the powerless, however, can take place only as a process of mutual extraction. This, we suggest, constitutes the normative structure of social capital among our young respondents and it is to its various manifestations that we now turn.

\section{'Dvizhukha': the rhythm of the hustle}

In the post-Soviet period, deprived of its heroic gloss, work in the mines is no longer a model of successful professional realisation. Only 3 of the 32 respondents in this study worked in the mines and most sought 'professional' and flexible employment rather than the rigid, repetitive and monotonous manual labour previously venerated:

... you don't see anything. You get in from work at 7. By the time you've got changed, washed, it's already fucking 8 . You go out for a couple of hours, and that's it - stupor.

(Sania-baton, 18, regular cannabis and amphetamine user, 2007)

However, the 'work hard, play hard' ethos of the past remains and the ability to live life to the full is a key marker of success. Today, the capacity to do so is not provided in the weekly pay packet, but has to be earned or supplemented via informal economic practices.

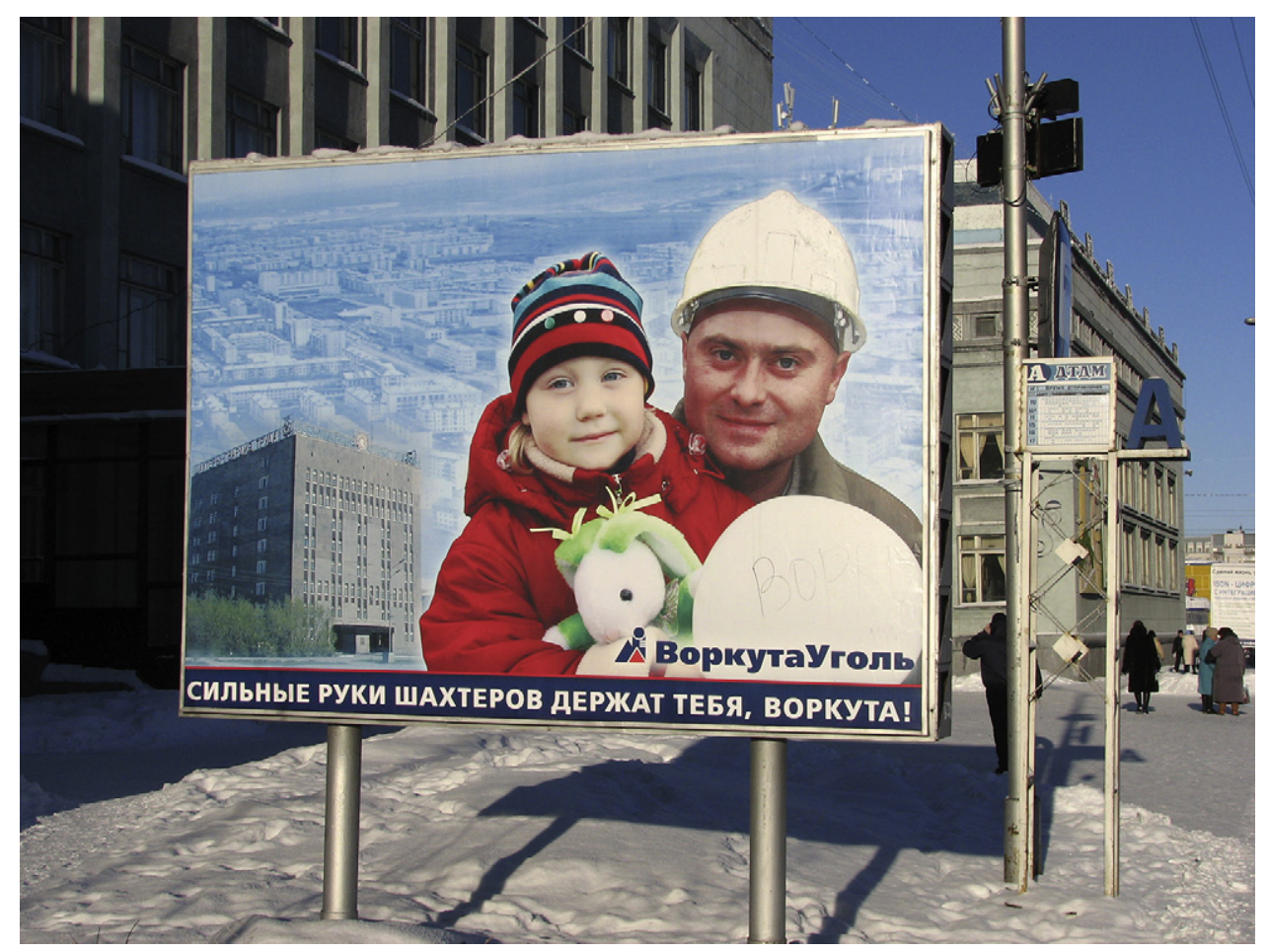

Plate 2. Billboard on the main street (Ulitsa Lenina) of the city, October 2006. The caption reads 'Vorkuta, you are in the strong arms of the miners'. 
Daily life is thus performed to a rhythm of earning and spending referred to by respondents as 'dvizhukha' ('hustle'):

Respondent: ... I mean the hustle kind of directs what you do. First of all you earn money, then you spend the money on relaxing. . .

Interviewer: So one follows the other?

Respondent: One hustle is a [successful] con, the next one goes down [is unsuccessful].

Interviewer: Or someone sends it down?

Respondent: If that happens it's not a hustle.

(Andrei, 23, regular cannabis and amphetamine user, 2006)

The (albeit imperfect) translation of 'dvizhukha' as 'hustle' captures both the Russian root of the word suggesting movement or energetic activity, but also the implication that fraud or deception is routinely employed. However, dvizhukha additionally implies the feeling of fulfilment in the experiencing or consumption of the thing hustled (money, sex, communication or drugs). Moreover, in Russian slang the same root links the expression directly to the use of drugs; the verb dvigatsia/dvinutsia means to 'shoot up' (Ufo, 1997, p. 26). All of these meanings are captured in this explanation of the everyday practice of dvizhukha by Murzilka:

Respondent: 'Brothers' (patsany) are those who... well, yeah, who are involved in certain kinds of business and who are in the hustle (dvizhukha), while lads (parni) are those who just get on with their own lives, who work on their own... Brothers hustle, they control stuff and all that.

Interviewer: So what is meant by 'dvizhukha'...what does dvizhukha actually mean?

Respondent: It depends whose dvizhukha you're talking about. Interviewer: [laughs]

Respondent: A junkie's dvizhukha for example is - waking up in the morning, realizing you need to sort something by evening, getting a fix and relaxing afterwards. Or dvizhukha can be going out somewhere, getting off your head somewhere. Somebody else's dvizhukha might be waking up and starting work, I mean their daily routine. Me, I have no dvizhukha. I've been just sitting at home for 2 weeks now. . . [laughs]...

(Murzilka, 2006)

Thus 'hustling' involves the capacity to engage oneself in the constant circulation of resources and to realise those resources through informal economic practices. Central to these practices are the purchase and sale of drugs. Fraud and deceit are also routinely employed to exploit the role of being an intermediary in these processes. However, 'hustling' is, by necessity, a social act since successful hustles require social networks to both make a quick buck and to spend it. Here Sania-baton reflects on the networks needed and the pros and cons of getting involved in the supply side of cannabis:

Interviewer: How come you've started smoking [cannabis] more often now?

Respondent: It's just that now it's there. Before it was a hassle getting hold of it, getting it off someone. But now it's okay, you just go up and get it, that's all there is to it.

Interviewer: And why was it a hassle before?

Respondent: Well, it's down to not knowing enough people. But when you know enough people, you just go up, that's it.

Interviewer: Does that all come with experience, knowing people?

Respondent: Well, yeah. First, you have a smoke with someone who has some, then you get some via someone else, then you do it directly yourself or sometimes you are phoned, 'D'you want something?' And you go 'No, I don't need anything.' Interviewer: So sometimes they phone you directly and offer you stuff?

Respondent: No, [that happens] only when it's a sound lad like my classmate for example, phoned me himself and asked if I knew anyone who wanted something or whether I wanted something. I took some myself.

Interviewer: Oh, I see. Had he bought more than he could use or something?

Respondent: Who, my classmate? Yeah, he works it as well. Interviewer: You mean he sells on?

Respondent: Well, yeah.

Interviewer: And those who sell on, do they make good money? Respondent: Pretty good. Well, if you buy wholesale for 350 [pauses, sighs], then you are likely to come out with 400 [roubles] profit.

Interviewer: That's if you sell on the whole box, yeah? I see, and where do they get the boxes?

Respondent: Well they work directly with the gangsters. Interviewer: And does everything to do with grass have to go through the gangsters?

Respondent: Who else? If I import [some cannabis], who the hell else am I going to sell the bulk of it to? ... it's easier and simpler to go to the gangsters. Otherwise you might get cheated or something.

(Sania-baton, 2007)

Drugs are also a key component of the consumption end of 'hustling'; making money is followed by memorable nights spending it 'getting off your head'. Below Andrei describes a particularly memorable New Year:

Interviewer: And what's been the most interesting thing you've tried?

Respondent: I liked the mushrooms.

Interviewer: And when was the first time you tried speed or tablets [amphetamines]?

Respondent: At New Year, 3 years ago.

Interviewer: Did somebody just have some or did you decide to go and buy them?

Respondent: No, I just went to somebody's I knew and bought them from him.

Interviewer: Were you thinking that you'd like to do something new at New Year or something?

Respondent: Well, maybe, I wanted something new, to celebrate it completely differently.

Interviewer: And how did it turn out?

Respondent: It was brilliant.

Interviewer: Yeah? Go on, go on...

Respondent: I was celebrating New Year for three whole days... [laughs]

Interviewer: Did you do $3 \mathrm{~g}$ or something? [Laughs]

Respondent: No. I just kept moving from one state to another. Interviewer: You mean from amphetamines to dope, from dope to amphetamines, then back to dope? Like that?

Respondent: You forgot the alcohol...

Interviewer: Alcohol?

Respondent: Yeah, basically, everything at once.

(Andrei, 2007)

In the remainder of this article, we explore the kinds of social networks and relationships young people forge in the pursuit and practice of dvizhukha and the normative structures in which these social networks operate. 


\section{Social capital: working the mutual extraction industry}

Income-generating 'hustling' practices are based on verbal agreements between individuals who are known to each other while not necessarily being 'joined up' members of a social network (see Pahl, 2000, pp. 6-7). They thus rely on networks whose bridging capital, we suggest, is not rooted in norms of 'reciprocity' (Halpern, 2005, p. 27) but mutual extraction. The hustles most frequently engaged in by respondents in this study were: trade in 'acquired' goods and drugs; money-lending; and 'sorting' disputes.

The most common way of making money was to buy and sell personal belongings. These are not always stolen goods - respondents sometimes sold personal items when they needed cash quickly but are usually small electrical appliances such as computer parts, mobile telephones or MP3 players.

Respondent: It's like if you have some capital - say 500 roubles you buy [something] from some idiot whose robbed something. He simply nicks a phone let's say from a girl. And you buy the phone from him for 500 roubles. It's clearly worth a lot more, naturally. You know how to value it, so you know your target profit. You want to get let's say, I don't know about 20\%. And you sell it to somebody who needs a phone like that right now. A telephone's just an example, it could be...

Interviewer: And how do you know where to find such a person? Respondent: A good way is through the local network, the internet. I dunno, you can always think of something. Friends of friends-those kinds of networks. You develop your own small network.

(Andrei, 2007)

A second common practice involved lending money. One respondent (Vitalii, 24, abstainer, 2007) had turned this into an informal business, charging a verbally agreed rate of 'interest', against a material guarantee and to a fixed repayment date. The verbal nature of such agreements is central to successful hustling since real profit is made when the debt is not repaid on time and the really smart hustler manipulates the situation such that this is frequently the outcome. In this sense the practice resembles Bourdieu's description of practices of symbolic violence in pre-industrial societies in which 'giving' is a way of creating personal indebtedness and securing, through personal intervention, relations of domination (Thompson in Bourdieu, 1991, p. 24).

This becomes particularly apparent in practices of moneylending not to strangers but to friends and acquaintances. In these practices social connectivity provides a constantly widening arena for discovering and accumulating knowledge about one another that can be used for personal profit or converted into symbolic capital. At the most benign level, knowledge acquired from social networks - length of acquaintance with the person, knowledge about what the money is for and the sources from which it will be returned - simply minimizes the risk of lending. However, where this acquaintance generates knowledge of an individual's weaknesses, the recognition of someone else's need for resource (money, contacts, protection) can be exploited for one's own profit:

Respondent: Serpent, for instance, has a lot of things which Danil'[left] because, for example, he needed some cash or something quickly. And Serpent is a right crafty bugger. He gives Danil' money, a loan basically, on that basis. He [Danil'] leaves something - a television or something - with him. Of course Danil' then goes and blows all the money in the slot machines and gives him nothing back. Serpent has plenty of things that Danil' has given him.

Interviewer: But Danil's completely skint isn't he?
Respondent: That's why he's skint, because he plays the slot machines. If you only knew how much he loses.

(Vitalii, 2007)

This manipulation of weakness is reminiscent of the exploitation of addiction among street crack dealers described by Bourgois (2003, p. 86) and the comparison becomes still clearer when the interviewer asks why no one has tried to help Danil' (23, regular cannabis and amphetamine user) with his gambling problem:

Respondent: ... For example I can tell you right now what I'll get out of it if I don't help [him]. But I can't say what use it will be to me if I do help him. I don't think I would get anything out of it.

Interviewer: Well simply that the person would stop doing something that is making life difficult for him.

Respondent: But it will cause me problems if that means I have less money in my pocket. And, you know, there are all kinds of sick people in the world, who like to play [the slot machines]. Should I be helping them all then?

(Vitalii, 2007)

In Vitalii's narrative, social connection and cooperation makes sense only if it has tangible advantages which can be converted immediately into something more useful, necessary or desired. This description of social relations as little more than a 'capitalist tool' appears to exemplify what Massumi (Zournazi \& Massumi, 2002, p. 228) calls the very 'subsumption of life under capitalism'.

\section{Cheating: mining the gap between words and deeds}

The informal economic practices described above are rooted in the observation by both parties of a verbal agreement. However, these practices are frequently disrupted by attempts by one or other party to turn the situation to his/her own advantage by breaking that agreement. The two most frequent forms of this are referred to as 'razvod' (a con) and 'kidalovo' (cheating). As a rule 'razvod' implies a significant degree of intention and pre-planning while 'kidalovo' is relatively opportunistic. In the extract below Murzilka describes a classic opportunity:

Respondent: We had to get hold of money somehow. We found some bizarre ways... one lad had a girlfriend and then they split up. The girl got herself a new bloke. And we basically gave that lad a hard time - saying like 'What do you think you're playing at?'... and we agreed to meet the next day to 'sort things out'. The next day we came but just talked about nothing much. We said, 'Come on, let's call a truce,' and all that. It was Saturday and we'd decided to go to the disco and have some beers. So we said, 'Let's call a truce - we'll both bring some beer - we'll bring two cases, and your lot should bring two cases.' They came to the meeting point [laughs]. We hadn't brought any beer. We took their beer and left [laughs]. And basically we drank ourselves silly for free. And so what? We had to relax somehow. None of us were working. We were all-some of us were still at school, some were students. There was no money coming from anywhere. So we found all kinds of victims.

Interviewer: So the point was just to get money?

Respondent: Well, yeah... well to get money and to make our mark. .

(Murzilka, 2006)

This action is a classic example of successfully out-smarting the other party; the skill lies in setting down conditions (verbally) 
in such a way that you can exploit the gap between words and deeds. Moreover, the lads gain not only materially, but also accrue symbolic capital; Murzilka acknowledges that 'the point', partially, was to establish the lads' status. However, another example of this indicates that the potential for the transformation of symbolic into real violence is always present. Volodia (18, abstainer, 2007) recounted how his uncle was being screwed for 3000 roubles by his 'friends' because he had failed to think quickly enough when they had sought to exploit an earlier debt. This situation had developed quickly and Volodia was concerned that when the inevitable meeting to 'sort things out' occurred, his uncle would be beaten up. Indeed, the practice of 'hiring friends' to intervene on your behalf (physically if necessary) in the event of a disputed agreement is another profitable hustling practice for those players blessed with physical rather than verbal skills. (This 'service' was offered to the main field researcher by one of the informants, when a third party failed to return loaned money.)

Since drug use involves a constant process of running resources (money and drugs), it is a frequent site for cheating (kidalovo). Murzilka spells out how street-level cultural capital can be manipulated to one's own advantage in the drugs market:

Respondent: How did we make money...? By cheating people who. . . kind of want to smoke but don't know where to get hold of it [cannabis]. We kind of offer our help-instead of cannabis we sell them dried nettles, dill, parsley, green tea. So what? One bloke [laughs]...He thought he was really cool and insisted we smoke with him [to test the quality]... So we filled a belomor [filterless cigarette] and I said, that I don't smoke cannabis, so I wouldn't smoke it but I would give him a blow-back. So we gave him a blow back but the lads simply blew it through their noses. . . basically we doped him up on nettles [laughs]. I don't remember whether he turned green or just pale, but he felt ill. And we asked - how's the grass - okay? [he answers] 'The grass is good' [laughs]. We took the money and left. Then we went and got ourselves some normal grass. So what, if he's a prat.

(Murzilka, 2006)

Other respondents reported having sold cannabis after mixing it with dill (Sania-baton, 2007) or having been the victims of such cheating (Katia, 21, former amphetamine, regular cannabis user, 2007). Danil' had been sold amphetamines ('spidy') which had had no effect; according to Murzilka (2006), who had also used some of it, it had been adulterated and was 'three-quarters anal'gin [a common analgesic bought over the counter in Russia]'. But Danil' himself had sold spidy on to friends 'after he had mixed the speed with some tablet or other' (Sharifullina, Fieldwork diary, 21 st October 2006).

Cheating friends, and family, in our study, was routine, universal and sometimes a goal in itself as well as a means to an end. This partially confirms Allan's (1989, p. 20) argument that the instrumental use of friendships 'play[s] a larger part in the routine organisation of daily life than is normally assumed'. However, his research suggests that while friends might use each other for certain purposes 'instrumentality should not be the basis or rationale for the relationship' (Allan, 1989). As Sania, makes clear below, however, this did not necessarily hold true for respondents in our study:

Respondent: Yeah. I cheated everyone, lived only for myself. In general, I didn't give a damn about anybody. I hung out with others only for what I could get out of it. I just squeezed every last drop out of people. What I needed - that's how it was basically. . . went here and there, had a great time, went to gigs, got high, went here, smoked, this, that and the other, and all for free, all without money.

(Sania, 23, former regular cannabis user 2007)

When we met Sania he had recently been diagnosed with diabetes and, as a result, had been forced to significantly curtail his alcohol and drug use (after a couple of bad experiences with attempts to continue cannabis use he gave up this and all alcohol other than vodka). His diagnosis, together with a life-changing revelation (between the two periods of fieldwork) that he was adopted, had caused him to reflect extensively on his life and this clearly affects the way in which he narrates his story. However, the full ethnographic data from the project suggest that the description he gives here of his 'former' life is not unwarranted and that he retained a high degree of instrumentality in both his friend and family relationships even after these 'turning points'.

Family or romantic relations are also a frequent site of conning and cheating. Sania-baton (2007) recounts a recent episode where he and his mates had taken advantage of a girl who was attracted to one of them. They hung out at her place every night for a month-being supplied with beer each evening at her cost. Before they 'disappeared' (having 'got bored with it') they asked her to lend them 600 roubles, claiming that they had broken something and needed to fix it. After she had lent the money they broke off all contact with her. Girls also frequently exploit boys' feelings as is evident from Lilia's account of how she and her friend often 'conned' lads for sex and money:

Respondent: ... Well if you want something, well you need money, to go out for example. If you haven't got any, but you want to, then you kind of say to a lad, that basically you'll be his, and you take money from this lad saying it will be safer with you and then you dump him. We did that kind of thing a lot...

(Lilia, 23, abstainer, 2006)

Lilia and Rita (22, abstainer, 2006) also cite the family as a common site of 'razvod'-parents in particular are conned into paying for things they want. Vitalii (2007) had helped a former friend (he was currently in dispute with him over an unpaid debt), Kolia-tushkan (19, regular amphetamine and cannabis user), cheat his mother out of proceeds from his parents' divorce settlement. Together they had cleared his father's flat of anything of value when they were warned that the bailiffs were coming to seize property. After the bailiffs had been, they moved it back in; the value extracted for Kolia-tushkan was that, since his father had moved out anyway, he had been offered the flat for his own use. Family, kin, intimate and friend relationships are particular sites of deception because these relationships allow maximum access to knowledge about people that can be manipulated for personal gain. In this nobody is sacred; when the interviewer expressed shock that Kolia-tushkan would cheat his own mother in this way, Vitalii responded simply, 'I couldn't give a damn who cheats whom'.

We have dwelt on the widespread practice and expectation of deception because, in discussions of social capital, significant attention is paid to the importance of levels of 'trust' in society as the prerequisite for mutual support and cooperation required for economic growth. Notwithstanding the suggestion by Round (2006, p. 27) that high levels of material and emotional trust are displayed among particular sections of the elderly community in Russia's far north, among our young respondents, even at the level of inter-personal relations, the starting position was often one of distrust: 
Respondent: ... in fact everyone is a scumbag. If somebody has not cheated you after a few months, then he/she moves into the status of 'decent'.

(Sania, 2007)

Here Sania demonstrates clearly that cooperation is not rooted in trust but based on a constant monitoring and sanctioning of others' actions (Misztal, 2000, p. 127). Moreover, this position is not understood as cynicism but as sensible caution and good business practice, confirming Kertman's (2006, p. 17) finding that, in post-Soviet Russia, people who do not trust others are perceived as clever, strong and independent and thus as more likely to be successful than those who, on the contrary, trust people. This suggests, once again, not that social (and indeed cultural and symbolic capital) are absent from social networks but rather that they are normatively differently constituted. As Hardin (2002, p. 96) suggests 'Trust is functional in a world in which trust pays off; distrust is functional in a world in which trust does not pay off'. Social relations in the world of our young respondents in Vorkuta clearly function on the basis of distrust.

\section{Conclusion}

In drug use literature, social networks and social capital have been discussed to date primarily in terms of their capacity to protect against risky or harmful practices. The argument presented in this article builds on evidence from existing empirical research (Miller \& Neaigus, 2001; Sherman et al., 2002) that, in certain situations, social connectivity can, on the contrary, increase exposure and vulnerability to risky drug use and sexual practices. It seeks, however, to offer something other than a new case study of drug use that identifies 'bad' as opposed to 'good' kinds of peer networks in terms of their role in preventing or increasing harm. Rather, it has taken the experience of a group of young people for whom drugs, as a commodity for sale, exchange and consumption, are central to their social networking as the basis for questioning assumptions we make about the nature of social capital. It has suggested also that the notion of social capital might be rendered a more useful category for the understanding of risk environments and drug using behaviour if the theoretical nod to the significance of 'attendant norms' or 'normative structures' in which it is embedded were to be fleshed out through empirical research.

On the basis of a small ethnographic study, this article has made an initial attempt to explore the normative structure of social capital in a city in the Russian far north. The findings presented suggest that social networks are alive and well in post-Soviet society but may function as sites of mutual extraction rather than mutual support and be governed by norms of distrust and anticipation of deceit rather than trust. We have argued also that the normative structure of social capital reflects wider capital relations underpinning the macro- and microrisk-environment. In the case presented here, we suggest this environment might be described as one in which the economy has been marketized but the self-regulating economy is not yet secured in objectified institutions that render legitimate, or invisible, the differential appropriation of various kinds of capital. As a consequence, relations of domination in society are not reproduced automatically but laid bare, visible and thus open to individual intervention.

At the level of the microrisk-environment, it has been suggested, Vorkuta is particularly illustrative of these processes because of the 'extreme' form of its deindustrialisation but also its cultural heritage in which (prison camp) labour was extracted in a particularly brutal manner in the early Soviet period while, in the post-war era, the labour of miners prepared to toil in the harsh conditions of
Russia's far north was highly rewarded both materially and symbolically. As industrial production is wound down in the city and the population debates whether they are working the mines or the mines are working them (since it is cheaper to keep the mines open than move the people), young people seek to generate the resource to 'play hard' in the 'new Russia' through informal economic opportunities. This engenders a range of 'hustling' practices deployed by young people which are rooted in networks that serve to accumulate knowledge about others that can be used to one's own advantage. Thus, we suggest, future research might usefully move on from measuring the relative 'volume' of social capital in 'transition' societies and consider further the form of social capital produced by young people's labour in this mutual extraction industry.

\section{Conflict of interest}

None.

\section{Acknowledgements}

The project from which empirical material is drawn for this article is funded by the European Commission (STREP-CT-CIT5029013) and coordinated by Egidija Ramanauskaite-Kishkina, Vytautas Magnus University, Lithuania (see: http://sal.vdu.lt/). The empirical research was conducted by a collaborative team from University of Warwick (led by Hilary Pilkington) and 'Region', Ul'ianovsk State University (led by Elena Omel'chenko). The earlier research referred to in the methods section was conducted with the financial support of the ESRC under the Research Grants Scheme ('Everyday but not normal: Drug use and youth cultural practice in Russia', Ref. R000239439). The project was a collaborative one between the University of Birmingham, UK (led by Hilary Pilkington) and 'Region' (as above, led by Elena Omel'chenko). The authors would like to acknowledge other team members - in particular Al'bina Garifzianova and Elena Omel'chenko - for their role in fieldwork in Vorkuta and to thank the anonymous reviewers for their helpful comments on the first draft of this article.

Please note that official statistical data cited in this article are dawn from the following electronic sources: http://komi.gks.ru/ r01/NASELEN_gr2.htm; http://komi.gks.ru/r02/NASELEN_gr.htm; http://vorcuta.ru/industry.htm; http://komi.gks.ru/r03/Ur-gizz. htm; http://www.gks.ru/gis/D_02.htm; http://www.gks.ru/bgd/ regl/b07_16/IssWWW.exe/Stg/02-10.htm; http://www.gks.ru/ bgd/regl/b07_13/IssWWW.exe/Stg/d01/04-23.htm; http://www. gks.ru/bgd/regl/b07_13/IssWWW.exe/Stg/d02/06-09.htm.

\section{References}

Allan, G. (1989). Friendship: Developing a sociological perspective. London: Harvester Wheatsheaf.

Bourdieu, P. (1977). Outline of a theory of practice. Translated by Richard Nice. Cambridge: Cambridge University Press.

Bourdieu, P. (1991). In John B. Thompson (Ed.), Language and symbolic power. Cambridge: Polity Press (Edited and with an introduction by John B. Thompson)

Bourgois, P. (2003). In search of respect: Selling crack in El Barrio (2nd ed.). New York: Cambridge University Press.

Fine, B., \& Green, F. (2000). Economics, social capital and the colonization of the social sciences. In S. Baron, J. Field, \& T. Schuller (Eds.), Social capital: Critical perspectives. Oxford: Oxford University Press.

Flaker, V. (2002). Drugs and transition. International Journal of Drug Policy, 13, $469-470$.

Halpern, D. (2005). Social capital. Cambridge: Polity Press.

Hardin, R. (2002). Trust and trustworthiness. New York: Russell Sage Foundation.

Kennedy, B. P., Kawachi, I., \& Brainerd, E. (1998). The role of social capital in the Russian mortality crisis. World Development, 26(11), 2029-2043.

Kertman, G. (2006). Mezhlichnostnoe doverie v Rossii. Sotsial'naia Real'nost', 4, 7-24.

Lalander, P. (2003). Hooked on heroin: Drugs and drifters in a globalized world. Oxford/New York: Berg. 
Latkin, C., Forman, V., Knowlton, A., \& Sherman, S. (2003). Norms, social networks, and HIV-related risk behaviours among urban disadvantaged drug users. Social Science \& Medicine, 56, 465-476.

Lovell, A. (2002). Risking risk: The influence of types of capital and social networks on the injection practices of drug users. Social Science $\mathcal{E} '$ Medicine, 55, 803-821.

MacDonald, R., \& Marsh, J. (2005). Disconnected youth? Growing up in Britain's poor neighbourhoods. Basingstoke: Palgrave Macmillan.

McKee, M. (2002). Substance use and social and economic transition: The need for evidence. International Journal of Drug Policy, 13, 453-459.

Miller, M., \& Neaigus, A. (2001). Networks, resources and risk among women who use drugs. Social Science \& Medicine, 52, 967-978.

Misztal, B. (2000). Informality: Social theory and contemporary practice. London/New York: Routledge.

Outhwaite, W., \& Ray, L. (2005). Social theory and postcommunism. Oxford: Blackwell.

Pahl, R. (2000). On friendship. Cambridge: Polity Press.

Parker, H., Bakx, K., \& Newcombe, R. (1988). Living with heroin: The impact of a drugs 'epidemic' on an English community. Milton Keynes, Philadelphia: Open University Press.

Pearson, G. (1987). The new heroin users. Oxford: Basil Blackwell.

Pilkington, H. (2007a). Beyond 'peer pressure': Rethinking drug use and 'youth culture'. International Journal of Drug Policy, 18, 213-224.

Pilkington, H. (2007b). In good company: Risk, security and choice in young people's drug decisions. The Sociological Review, 55(2), 373-392.

Putnam, R. (1995). Tuning in, tuning out: The strange disappearance of social capital in America. Political Science and Politics, 28, 664-683.

Reimer, B., Lyons, T., Ferguson, T., \& Polanco, G. (2008). Social capital as social relations: The contribution of normative structures. The Sociological Review, 56(2), 256-274.

Rhodes, T., \& Quirk, A. (1998). Drug users' sexual relationships and the social organisation of risk: The sexual relationship as a site of risk management. Social Science E' Medicine, 46(2), 157-169.
Rhodes, T., \& Simic, M. (2005). Transition and the HIV risk environment. BMJ, 331 220-223.

Rhodes, T., Singer, M., Bourgois, P., Friedman, S., \& Strathdee, S. (2005). The social structural production of HIV risk among injecting drug users. Social Science $\mathcal{E}$ Medicine, 61, 1026-1044.

Rose, R. (1995). Russia as an hour-glass society: A constitution without citizens. East European Constitutional Review, 4(3), 34-42.

Round, J. (2005). Rescaling Russia's geography: The challenges of depopulating the Northern Periphery. Europe-Asia Studies, 57(5), 705-727.

Round, J. (2006). Marginalized for a lifetime. The everyday experiences of gulag survivors in post-Soviet Magadan. Geografiska Annaler, 88 B(1), 15-34.

Sherman, S., Smith, L., Laney, G., \& Strathdee, S. A. (2002). Social influences on the transition to injection drug use among young heroin sniffers: A qualitative analysis. International Journal of Drug Policy, 13, 113-120.

Shildrick, T. (2002). Young people, illicit drug use and the question of normalization. Journal of Youth Studies, 5(1), 35-48.

Springer, A., Parcel, G., Baumler, E., \& Ross, M. (2006). Supportive social relationships and adolescent health risk behavior among secondary school students in El Salvador. Social Science \& Medicine, 62, 1628-1640.

Ufo (Valery Nikolski). (1997). Russian-English dictionary of contemporary slang. Nottingham: Bramcote Press.

White, A. (2004). Small-Town Russia: Postcommunist livelihoods and identities. London: RoutledgeCurzon.

Yates, S. (2005). Living with poverty in post-Soviet Russia: Social perspectives on urban poverty. PhD thesis, London: University of London (LSE).

Zinberg, N. (1984). Drug, set, and setting: The basis for controlled intoxicant use. New Haven/London: Yale University Press.

Zournazi, M., \& Massumi, B. (2002). Navigating movements: A conversation with Brian Massumi. In M. Zournazi (Ed.), Hope: New philosophies for change. University of Wollongong. Available on-line at http://ro.uow.edu.au/ cgi/viewcontent.cgi?article $=1087 \&$ context=artspapers 